の

他

る。我々も同様な奇形の再形成にあたつて、AbbeNeuber 原法もしばしば行つているが、人中部形態の 適合に好都合な所謂M型の Vermilionflapを応用し て、Cupid's bowの形成、prolabium の全欠損によ る人中、white skin roll の形成が奇麗に出来、好結 果を得えたので、その数例を紹介すると共にその征式 を $8 \mathrm{~mm}$ 映写によつて、供覽した。

\section{5. 顎関節の規格撮影について}

(放射線) 。佐藤信正、香山 篤、大庭 健、 森 進一郎

1) 研究目的

顎関節は複雑な形態に加えて、その周囲を頭部の骨 にて册まれているために、撮影方法、撮影角度によつ ては顎関節の影像も種々様相を異にしてくるものであ る。従つて常に同一条件のもとに撮影される即ち規格 撮影力゙必要となつてくる。

2 ) 研究方法

オランダ製エルマシエナンデルの頭部精密撮影装置 にて焦点フイルム間距潅 $72.0 \mathrm{~mm}$ 亿てブッキーブレン デ併用撮影を行つた。

3 ) 成 績

現在の所、思部の固定が充分でないので改良を行う 点もあるが、各角度が確実に記録されるために、従来 のものに比較して同一条件撮影力゙行いやすくなつた。

\section{4) 考 察}

顎関節の形態は立体像を呈しているため、一枚の平 板上のフィルム面に一方向のみの撮影では允分でるい 場合が多い。か〉る意味あいで常に二方向より、更に 必要によつては数種の撮影方向より得たX線像にて診 断を必要とする場合もある。

しかしながら、これらの撮影に执いても、常に替格 化を考えて㧍放ば、正確なる比較が出来ないもので ある。

我々は今后エルマシエナンデルの装置により、顎関 節の規格撮影を体形ずけていく所存である。

\section{6. エポキシ樹脂を基材とする根管充埥浏に関す る実験的研究（第 2 報）}

(保存) 吉田光雄、山本博武、佐伯栄一、 㖅尾搏已、村岡俊彦、北村勝也

從来より根管充填凨の所要性質に関しては Miller 以来多くの学者によつて述べら、また追加されてい る。
しかるに今日に於てもこれらの諸条件を満足させ得 る根管充填㓣は見当らない状態である。

われわれの教室に执いても新しい根管充嗔用の創製 のため一連の研究を進めている。その一部として有機 性高分子化物エポキシ樹脂を基材とした根管充填剂 $\mathbf{A}$ H26について

1 ）加重による粘度測定

2）回転式粘度計（Viscotester）による粘度測定

3 ）収縮性（Comparator による測定）

4 ）組織反応について各種根管充填郕との比較実験 を行い。

次の結論を得た。

1）粘舻性については他の根管充塤剤と比較して適 度の粘调性を示した。

2 ）収縮性、すなわち容積不变性はとくに優れてい Ђ。

な扣、ラツテ皮下組織内に於る組織反応については 実験検索中であるので次回に報告する。

\section{7. 口腔疾患治療中に現われた帯状疮疮について} (口外) 巨山 保、馬渡和夫、。蒲池世史郎、 池 伸和

最近私澾は口腔疾患治療中の6 名の患者に発生した 帯状陁装と水痘を経験したので報告する。症例 1 は炤 和39年 8 月18日、左側三攴神経第 I II枝領の帯状狍掺 として来院した54才の女性であり、症例 2 は昭和40年 1 月13日、下㖽悪性腫瘍術後の57才の男性に現われた 右側頸及び胸神経領の帯状跑突で、その経過中、下顎 骨々折手術後の 3 才の幼児に現われた水痘をはしめ、 約 1 ケ月關に隣在する病室の乳奣 3 名に同様に水痘の 発症を㒻た。これら乳㸺 3 名は唇顎及び口蒀裂の奇形 を有する術前後の患者であつた。以上報告した6症例 は、いずれも口腔疾患治療中に遭遇した带状佨骖及び 水痘であり、その内わけは帯状敂牀 2 例、他は乳幼少 にみた水痘であつた。症例 2 以後の 5 例は比較的短期 間の中に隣在する病室で発症したものであり、Bókay が云う带状疱疹と水痘の一元論が何えるのではないか と思う。

\section{8. 口腔外科手術における EDH-Adhesive (Bioband) の使用経験について}

(口外) 巨山 保、蒲池世史郎、。池 伸和

外科手術が始つて以来、離断された組織を強固且つ 容易に接合するととは極めて重要な手術操作の一つで 